\title{
Current perspectives on the role of IL-I7 in autoimmune disease
}

\author{
This article was published in the following Dove Press journal: \\ Journal of Inflammation Research \\ 17 June 2010 \\ Number of times this article has been viewed
}

\author{
Hisakata Yamada \\ Division of Host Defense, Medical \\ Institute of Bioregulation, Kyushu \\ University, Fukuoka, Japan
}

Correspondence: Hisakata Yamada Division of Host Defense, Medical Institute of Bioregulation, Kyushu University, 3-I-I Maidashi, Higashiku, Fukuoka, 8I 2-8582 Japan

Tel +8I 926426962

Fax +8I 926426973

Email hisakata@bioreg.kyushu-u.ac.jp
Abstract: Until recently, autoimmune diseases had been categorized as either Th1- or Th2-mediated diseases. However, the discovery of a novel subset of helper T cells producing interleukin (IL)-17, ie, Th17 cells, changed this paradigm. Currently, IL-17 and Th17 cells are implicated in many autoimmune diseases, such as rheumatoid arthritis, psoriasis, multiple sclerosis, and inflammatory bowel diseases. Such conclusions were initially drawn from observations in animal models of autoimmune diseases, and accumulating data from clinical research also support the involvement of IL-17 in human diseases as well. Reagents targeting Th17-related molecules have been under clinical investigation for some diseases but have not always been effective in controlling disease activity. Consistent with this, it has become evident that there are substantial differences in the development of Th17 cells and in the way they function in autoimmune diseases between humans and experimental animals. Thus, further investigation is needed before we can draw any conclusions about the importance of IL-17 and Th17 cells in human autoimmune diseases.

Keywords: IL-17, Th17, rheumatoid arthritis, multiple sclerosis, Crohn's disease, psoriasis

\section{Introduction}

The introduction of biologicals for treatment of autoimmune disorders has dramatically changed the prognosis of these diseases. However, there are patients who are refractory to this treatment, and the frequency of patients who achieve drug-free remission is very low. This might indicate limitation of the current therapy targeting nonspecific inflammatory cytokines, such as tumor necrosis factor-alpha (TNF $\alpha$ ). Therefore, development of a novel treatment strategy targeting molecules or cells that are closer to the etiology of autoimmune diseases is desired. Until recently, it was widely accepted that autoimmune diseases are categorized as Th1- or Th2-mediated diseases. The former includes Crohn's disease (CD), psoriasis, rheumatoid arthritis (RA), and multiple sclerosis (MS), while the latter includes asthma, systemic lupus erythematosus (SLE), and ulcerative colitis (UC). However, the Th1/Th2 paradigm of autoimmune diseases included substantial discrepancies and was questioned by the discovery of a novel helper T cell subset, ie, Th17 cells, producing interleukin (IL)-17, firstly in mice, and a couple of years later in humans. Currently, many autoimmune diseases are believed to be Th17-mediated diseases, because the biologic functions of IL-17 are consistent with the chronic and destructive nature of inflammation. This review introduces accumulating evidence on the roles of IL-17 and Th17 cells in human autoimmune diseases. 


\section{Biology of IL-I 7}

IL-17 (IL-17A) was discovered in 1993 originally as a rodent T cell cDNA transcript, cytotoxic T lymphocyte-associated antigen 8 (CTLA8). ${ }^{1}$ Human IL-17 was subsequently identified. $^{2}$ To date, five additional members of the IL-17 family have been identified and termed IL-17B, C, D, E, and F. IL-17F is most closely related to IL-17, and can form a heterodimer with IL-17, while IL-17E, also named IL-25, is instead classified as a Th2 cytokine. ${ }^{3}$ There are five receptors for the IL-17 family of cytokines, ie, IL-17RA, RB, RC, RD, and RE, of which IL-17RA and RC mediate the biologic activity of IL-17. While IL-17 is produced mainly by T cells, its receptor is expressed ubiquitously on various cell types, including myeloid cells, epithelial cells, and fibroblasts. Therefore, IL-17 exerts various biologic functions in vivo, which might be involved in the pathogenesis of a wide range of inflammatory disorders, as well as infectious conditions (Figure 1).

One of the well-defined functions of IL-17 is mobilization of neutrophils, which is mediated by the production of CXC chemokines, including IL-8 (CXCL8) and growth-regulated oncogene-alpha (GRO $\alpha, \mathrm{CXCL} 1)$, and growth factors, including granulocyte colony-stimulating factor (G-CSF) and granulocyte macrophage colony-stimulating factor (GM-CSF), from epithelial cells and smooth muscle cells, as well as fibroblasts. ${ }^{3,4}$ In fact, murine models of infection

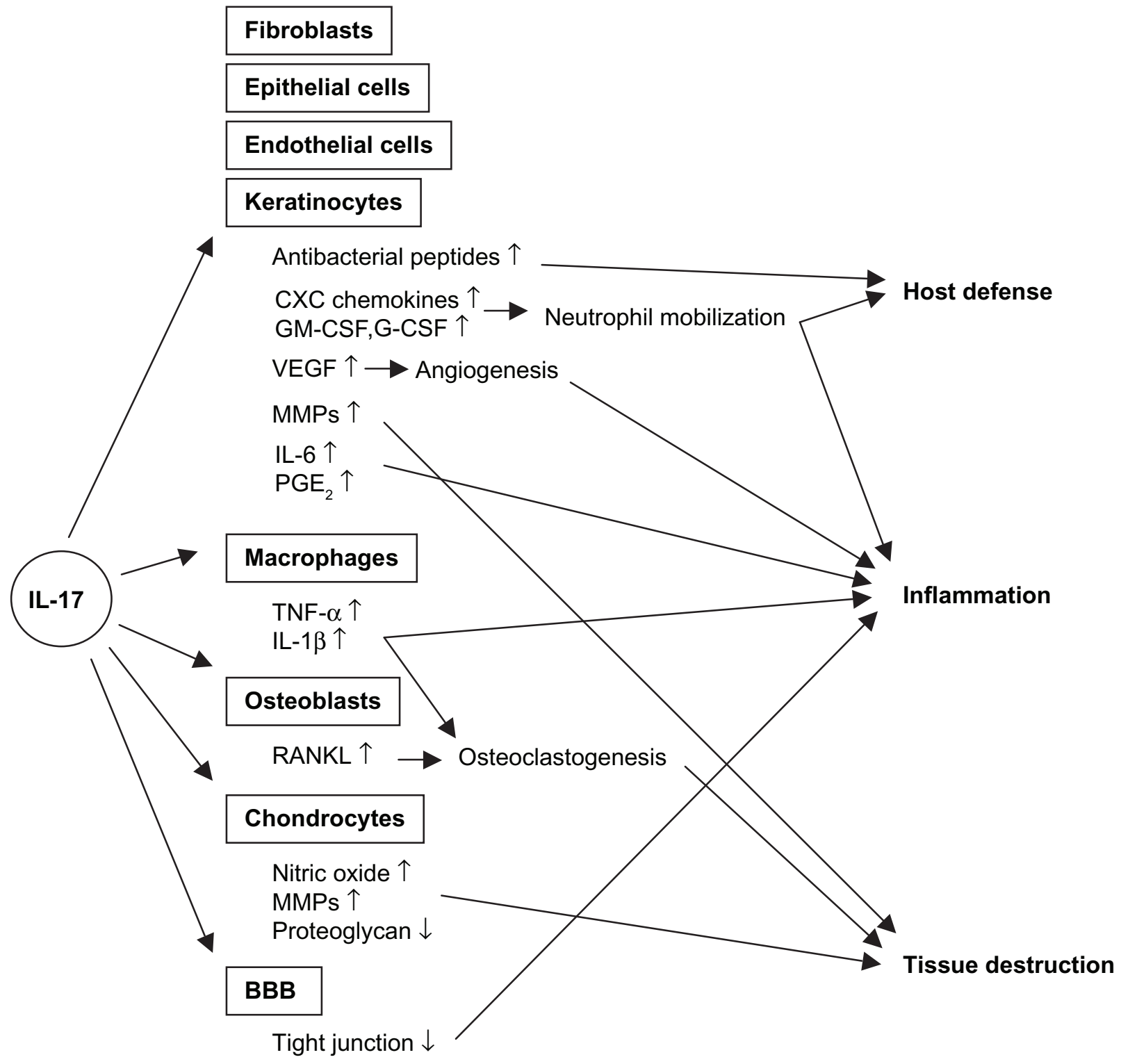

Figure I Effects of IL-I7 signaling on host defense, inflammation, and tissue destruction.

Abbreviations: BBB, blood-brain barrier; G-CSF, granulocyte colony stimulating factor; GM-CSF granulocyte macrophage colony stimulating factor; VEGF, vascular endothelial growth factor; MMPs, metalloproteinases; $\mathrm{PGE}_{2}$, prostaglandin $\mathrm{E}_{2}$; TNF- $\alpha$, tumor necrosis factor-alpha. 
showed the involvement of IL-17 in neutrophil-mediated host defense against extracellular bacteria and fungi, such as Klebsiella pneumoniae, Escherichia coli, and Candida albicans. ${ }^{5}$ A role for IL-17 in mycobacterial infection, in which macrophage activation is important for host defense, was also reported. Furthermore, IL-17 participates in the elimination of pathogens by inducing antimicrobial peptides, such as $\beta$-defensins, especially in cooperation with IL-22. ${ }^{6}$ Some studies suggest the role of IL-17 in human host defense mechanisms as well. Acosta-Rodriguez showed that human memory T cells specific for C. albicans produced IL-17. Patients with hyper-IgE syndrome, who are defective in IL-17 production, are susceptible to bacterial and fungal infections. $^{8}$

IL-17 exerts various biologic activities, which potentially cause tissue destruction and degeneration during chronic inflammation. IL-17 stimulates macrophages to produce various inflammatory cytokines, such as IL-1 $\beta$ and TNF $\alpha$. Furthermore, IL-17 acts synergistically with TNF $\alpha$ in IL-6 and GM-CSF production from fibroblasts. ${ }^{4}$ Of particular importance in the pathogenesis of RA is that IL-17 induces cartilage destruction via induction of metalloproteinases and inhibition of proteoglycan synthesis. IL-17 induces expression of RANKL on osteoblasts that mediates osteoclastogenesis, leading to bone destruction in RA. ${ }^{10,11}$ Regarding intestinal inflammation, IL-17 stimulated metalloproteinase, IL-6, and IL-8 production from cultured colonic subepithelial myofibroblasts. ${ }^{12}$ IL-17 also upregulates production of GMCSF, IL-6, and GRO- $\alpha$ from keratinocytes. ${ }^{13}$ In the central nervous system, IL-17 was shown to disrupt the blood-brain barrier tight junction, which facilitated local migration of CD4 T cells. ${ }^{14}$ All these findings suggest an involvement of IL-17 in the pathogenesis of various autoimmune diseases affecting a number of tissues.

\section{ThI 7 cells}

As is the case for most $\mathrm{T}$ cell-derived effector cytokines, an initial study demonstrated IL-17 production by CD45RO+ memory T cells. ${ }^{4}$ Subsequently IL-17 was shown to be produced by Th1, Th0, and even Th2 cell clones. ${ }^{13,15}$ However, later studies in mice demonstrated by flow cytometric analysis of intracellular cytokine staining that IL-17-producing cells are characterized as a subset of helper T cells, which do not produce interferon gamma (IFN $\gamma$ ) or IL-4, the development of which was negatively regulated by IFN $\gamma$ and IL-4, which are prototypic cytokines of Th1 and Th2 cells, respectively. ${ }^{3}$ Thus, IL-17-producing CD4 T cells, which have been identified as a novel helper CD4 T cell subset distinct from
Th1 and Th2 cells, were subsequently named Th17 cells. Identification of human Th17 cells was also reported a couple of years later. ${ }^{7,16}$

Since the discovery of Th17 cells, the molecular mechanisms for their differentiation have been extensively studied. Initial studies showed that IL-23, a member of the IL-12 family of cytokines that consists of the common IL-12/23p40 subunit and the unique IL-23p19 subunit, induced differentiation of mouse Th17 cells. However, it was later suggested that IL-23 is involved in the maintenance, expansion, and functional maturation of Th17 cells. On the other hand, it is now widely accepted that naive mouse CD4 T cells primed with antigenic stimulation in the presence of transforming growth factor beta (TGF $\beta$ ) and IL-6 differentiate into Th17 cells. IL-21, which is produced by Th17 cells, can substitute for IL-6 in the differentiation of Th17 cells in an autocrine manner. ${ }^{3}$ Resulting downstream signaling events that include activation of STAT3, induce the expression of ROR $\gamma t$ and ROR $\alpha$, the master regulators of Th17 differentiation. ${ }^{17}$ Human Th17 cells also express the human ortholog of murine ROR $\gamma$ t, RORC2 ${ }^{18} \mathrm{~T}$ cells in patients with mutated STAT3 are unable to differentiate into Th17 cells. ${ }^{8}$ However, there seem to be substantial differences in the signal requirement for the differentiation of mouse and human Th17 cells. In mice, IL-23 does not directly induce the differentiation of Th17 cells. However, IL-23, in combination with IL-1 $\beta$, was repeatedly reported to play central roles in the differentiation of human Th17 cells, while the requirement for TGF $\beta$ in human Th17 differentiation is still controversial. ${ }^{3}$ Different sensitivity to TGF $\beta$ in the serum used for in vitro culture and different cellular sources used for the experiments are possible explanations for this discrepancy. Alternatively, TGF $\beta$ indirectly promotes Th17 development by inhibiting Th1 responses. ${ }^{19}$ Interestingly, human Th17 cells were demonstrated to originate from CD161+ cells. ${ }^{20}$ CD161 is the human homolog of NK1.1 in mice. However, neither mouse Th17 cells nor IL-17-producing invariant NKT cells express NK1.1. ${ }^{21}$ Thus, there are substantial differences between human and mouse Th17 cells.

Expression of CCR6 is a common feature of mouse and human Th17 cells, ${ }^{7,16,22}$ although it should be kept in mind that not all CCR6-positive cells are Th17 cells. Th17 cells migrate toward CCL20, the ligand for CCR6, but also secrete CCL20. Therefore, there might be a positive feedback loop of chronic accumulation of Th17 cells once inflammation is provoked. Th17 cells produce several kinds of inflammatory cytokines in addition to IL-17 and IL-17F, which include TNF $\alpha$ and IL-6, IL-21, IL-22, and IL-26. It is worth noting 
that not only IL-6 and TNF $\alpha$, but also other cytokines, can be produced by other subsets of CD4 T cells. For example, IL-21 is more likely a product of follicular helper T cells, which can be derived from Th1 and Th2 cells as well. ${ }^{23}$ In addition, not all IL-17-producing cells are positive for IL-21. Similarly, a large part of the IL-22-producing cell population does not belong to Th17 cells and is regarded as another independent subset of helper T cells, denoted as Th22 cells. ${ }^{24}$ Nevertheless, it is important to note that IL-22 and IL-17 cooperatively enhance expression of antimicrobial peptides. ${ }^{6}$ IL-22 is known to induce hyperplasia of keratinocytes involved in the pathogenesis of psoriasis (see below). IL-23 is also involved in IL-22 production. Thus, there are functional similarities between IL-17 and IL-22-producing T cells. As mentioned previously, IFN $\gamma$ suppresses the differentiation of Th17 cells in vitro. However, presence of CD4 T cells producing both IL-17 and IFN $\gamma$ has also been noted, especially in humans. Their origin and functions are not clarified yet, but phenotypic plasticity of Th17 to Th1 cells by IL-12-signaling has been demonstrated. ${ }^{16}$

In addition to Th17 cells, other subset of T cells, including CD8 T, NK T, and TCR $\gamma \delta$ T cells, have been demonstrated to produce IL-17 in mice. Even non-T cells, such as neutrophils and lymphoid tissue inducer-like cells, can also be an innate source of IL-17. ${ }^{25}$ Among them, $\gamma \delta$ T cells are the most well known as an important source of in vivo IL-17 production in some circumstances, not limited to infection conditions, ${ }^{5}$ but even in autoimmune diseases. ${ }^{26,27} \mathrm{IL}-17$ production by $\gamma \delta$ T cells as well as other populations of non-Th17 cells has also been reported in human, but its importance has yet to be determined.

\section{Implication of IL- I 7 and Th I 7 cells in autoimmune diseases Inflammatory bowel diseases}

$\mathrm{CD}$ and UC are the two major inflammatory bowel diseases (IBDs). Although CD and UC share some features, there are clear differences in the areas of involvement as well as histology, which are at least in part explained by their different cytokine profiles. Thus, it has been widely accepted that $\mathrm{CD}$ and $\mathrm{UC}$ are Th1 and Th2 diseases, respectively. ${ }^{28}$ Accordingly, animal models of IBD have also been subdivided into Th1 and Th2 types as the models of CD and UC, respectively. However, the discovery of Th17 cells have provided novel insight into the pathogenesis of IBD. It was revealed that IL-23 is essential for the development of $\mathrm{T}$ cell-dependent IBD models, in which IBD is induced by transferring naive CD4 $\mathrm{T}$ cells into $R A G$-deficient mice or developed spontaneously in IL-10-deficient mice. ${ }^{29,30}$ The latter is of particular interest, because it was recently reported that the $\mathrm{CD}$-associated mutation of the NOD2 gene suppresses IL-10 transcription. ${ }^{31}$ Neutralization of IL-23 exerted a therapeutic effect on the development of experimental colitis. ${ }^{32}$ These findings suggest the involvement of Th17 cells in the development of IBD mouse models. However, a protective role of IL-17 was also reported in the naive CD4 T cell-transfer model of colitis, ${ }^{33}$ although IL-17F might have opposite functions. ${ }^{34}$ Thus, the disease-promoting effect of IL-23 might not necessarily mediate IL-17 or Th17 cells. Actually, it was observed that the lack of IL-23 also reduced $\mathrm{Th} 1$ responses, and that blocking IFN $\gamma$ abrogated the development of the $\mathrm{T}$ cell transfer model of colitis. ${ }^{35}$ Furthermore, IL-23 promoted even T cell-independent models of colitis. ${ }^{29}$

Despite the controversies about the importance of the IL-23/IL-17 axis in IBD animal models, there have been reports showing overexpression of Th17-related molecules in human IBD lesions (see Table). IL-17 mRNA was expressed in inflamed colonic tissue from CD or UC. ${ }^{36}$ Expression of IL-17 in the intestine of CD and UC was also demonstrated by immunohistochemistry, in which highest levels of expression were detected in the active CD lesion. ${ }^{37}$ Expression of IL-23p19 was increased in inflamed mucosa. ${ }^{38,39}$ There are studies addressing other Th17-related cytokines. IL-22 was shown to be overexpressed in inflamed mucosa and serum

Table I Expression pattern of IL- I 7 and IL-23 transcripts in lesional tissue samples

\begin{tabular}{|c|c|c|c|c|}
\hline & IL-I 7 & IL-23p I 9 & IL-I 2/23p40 & Study (Ref) \\
\hline \multirow[t]{5}{*}{$\mathrm{IBD}$} & + & + & \pm & Neilsen et $\mathrm{al}^{36}$ \\
\hline & & & & Fujino et $\mathrm{a}^{37}$ \\
\hline & & & & Schmidt et $\mathrm{al}^{38}$ \\
\hline & & & & Holtta et $a^{39}$ \\
\hline & & & & Kobayashi et al ${ }^{47}$ \\
\hline \multirow[t]{6}{*}{ Psoriasis } & + & + & + & Teunissen et $\mathrm{al}^{50}$ \\
\hline & & & & Lowes et $\mathrm{al}^{51}$ \\
\hline & & & & Chan et a $\mathrm{a}^{52}$ \\
\hline & & & & Wilson et $\mathrm{a}^{53}$ \\
\hline & & & & Piskin et $\mathrm{a}^{58}$ \\
\hline & & & & Zaba et al ${ }^{129}$ \\
\hline \multirow[t]{6}{*}{ RA } & $-1+$ & + & $-1 \pm$ & Chabaud et al ${ }^{77}$ \\
\hline & & & & Kirkham et al ${ }^{85}$ \\
\hline & & & & Stamp et $\mathrm{a}^{86}$ \\
\hline & & & & Hillyer et al ${ }^{87}$ \\
\hline & & & & Kohno et $\mathrm{a}^{88}$ \\
\hline & & & & Brentano ${ }^{94}$ \\
\hline \multirow[t]{2}{*}{ MS } & + & + & + & Lock et al ${ }^{104}$ \\
\hline & & & & Li et al ${ }^{110}$ \\
\hline
\end{tabular}

Abbreviations: IBS, irritable bowel syndrome, RA, rheumatoid arthritis; ref, reference; MS, multiple sclerosis. 
of CD patients. ${ }^{40,41}$ IL-17F mRNA was also expressed at a higher level especially in UC. ${ }^{42}$ An involvement of IL-23signaling in the pathogenesis of IBD was also suggested by its genetic association with $I L 23 R$ polymorphisms. ${ }^{43}$ Genetic associations of CD with Tyk2 and STAT3, both of which are involved in IL-23-signaling, were also shown in a Japanese population. ${ }^{44}$

Human Th17 cells were first reported using samples from IBD patients, and there was an increase of IL-17+ cells in the gut of CD patients. ${ }^{16}$ Notably, many IL-17-producing $\mathrm{T}$ cells in the gut also produced IFN $\gamma$ (about 40\%). CD161+ Th17 cells are enriched in the lamina propria, even in healthy subjects, with a further increase in CD lesions. ${ }^{45}$ The percentage of IL-17-producing cells in CD161 + CD4 $\mathrm{T}$ cells in the peripheral blood also increased in $\mathrm{CD}$ patients. Interestingly, it was reported earlier that CD4 T cells in UC were enriched with IL-13-producing cells, which expressed CD161. ${ }^{46}$ Unfortunately, IL-17 production by CD161 + CD4 $\mathrm{T}$ cells was not expected at that time and therefore was not examined. Kobayashi et al demonstrated an increased frequency of Th17 cells in the lamina propria compared with peripheral blood. ${ }^{47}$ Lamina propria CD4 T cells in UC produced more IL-17 than those in CD, while IFN $\gamma$ production was higher in CD than in UC. The addition of IL-23 augmented both IL-17 and IFN $\gamma$ production of LP $\mathrm{CD} 4 \mathrm{~T}$ cells in vitro. It was also reported that the percentage of IL-17- and IFN $\gamma$-producing cells was higher in T cells in IBD lesions compared with control samples, but there was no difference between CD and UC. ${ }^{48}$ The number of macrophages secreting IL-23, TNF $\alpha$, and IL-6 increased in $\mathrm{CD}$, and they affected IFN $\gamma$, but not IL-17, production of lamina propria mononuclear cells, suggesting the presence of an IL-23/IFN $\gamma$ axis in the pathogenesis of CD. ${ }^{49}$ Therefore, although the relative importance of Th17 cells in human $\mathrm{CD}$ and UC is still unclear, IL-23 likely plays a critical role in the pathogenesis, which is now proved by the results of clinical trials described later in this paper.

\section{Psoriasis}

Psoriasis is a chronic inflammatory disease of the skin characterized by epidermal hyperplasia, dermal angiogenesis, and inflammatory cell infiltrates. Psoriasis had been generally regarded as a Th1 disease, but recent data suggest the involvement of Th17 responses. Expression of IL-17 mRNA was detected in biopsies from lesional psoriatic skin. ${ }^{50-53}$ Serum levels of IL-17 correlated with disease severity. ${ }^{54}$ Th17 cells were detected in inflamed skin, ${ }^{51,53}$ although an increase of Th1 cells was also observed. ${ }^{55}$ The accumulation of Th17 cells in psoriatic skin could be anticipated, because it was reported even before the discovery of Th17 that expression of CCL20 was upregulated in psoriatic skin, and skin-homing $\mathrm{T}$ cells express its receptor, CCR6 $6{ }^{56}$ Keratinocytes, dermal fibroblasts, microvascular endothelial cells, and dendritic cells produce CCL20. As mentioned above, CCL20 is also produced by Th17 cells, which might account for the chronicity of the disease.

Upregulation of IL-23 in psoriatic lesions was also repeatedly reported. Increased expression of IL-23p19 and IL-12/ IL-23p40 was noted in the lesional skin of psoriasis patients. ${ }^{52,57,58}$ Similar to IBD, association of the disease with the $I L 23 R$ gene polymorphism was demonstrated. ${ }^{59,60}$ The importance of IL-23 in the pathogenesis of psoriasis is also supported experimentally. Intradermal injection of IL-23 in mice induced psoriasis-like lesions with epidermal hyperplasia and inflammatory cellular infiltrate. ${ }^{52}$ Notably, TNF $\alpha$, but not IL-17, was required for the response. It was later revealed that IL-22 mediates the IL-23-induced dermal pathology. ${ }^{61} \mathrm{Ma}$ et al also demonstrated the requirement of IL-22 in another psoriasis model, which was induced by transferring naive CD4 $\mathrm{T}$ cells into scid/scid mice. ${ }^{62}$ The IL-22 receptor was not expressed on immune cells but rather on epithelial keratinocytes, in which IL-22 induced expression of antimicrobial peptides. ${ }^{63}$ IL-22 also regulates migration, proliferation, and differentiation of keratinocytes, suggesting roles of IL-22 in wound healing as well as skin inflammation. ${ }^{64}$ Furthermore, injecting IL-22 directly into the skin induced expression of antimicrobial peptide, and inflammatory cytokines and keratinocyte hyperplasia. ${ }^{62}$ In agreement with these findings, serum IL-22 levels increased in psoriasis patients and were correlated with disease severity. ${ }^{65}$ Local IL-22 expression increased in psoriatic lesions and was associated with increased expression of metalloproteinases and antimicrobial peptides. ${ }^{53,63,65}$ Although Th17 cells can produce IL-22, ${ }^{6,61} \mathrm{IL}-22$ production by another independent subset of helper T cells in psoriatic lesions was recently reported by several groups. ${ }^{24,66,67}$ These IL-22-producing cells produce neither IL-17 nor IFN $\gamma$, but share similarities with Th17 cells in the expression pattern of chemokine receptors. However, their detailed characteristics and functions are yet to be analyzed. These findings suggest the importance of IL-23 and IL-22, possibly more than IL-17, in the pathogenesis of psoriasis. It is also suggested that IL-17 and IL-22 have a distinct function in the pathogenesis of psoriasis, ie, IL-22 regulates keratinocyte differentiation, while IL-17 is more related to inflammation. ${ }^{68}$ 


\section{Rheumatoid arthritis}

RA is characterized by chronic inflammation of systemic synovial tissue, which leads to joint destruction. The well known disease association with major histocompatibility complex Class II genes and infiltration of CD4 T cells in synovial tissue implies that activation of autoreactive CD4 $\mathrm{T}$ cells drives chronic inflammation. The requirement of CD4 T cells for the development of arthritis in animal models also supports the idea. Massive infiltration of activated macrophages in RA synovium suggests the involvement of Th1 cells, which are well known to activate macrophages in the host defense against intracellular pathogens. Expression of Th1 cytokines in RA joints was also demonstrated. ${ }^{69}$ However, there has also been some data conflicting with the Th1 hypothesis, ie, mice blocking IFN $\gamma$-signaling were more susceptible to arthritis. ${ }^{70}$ Nevertheless, disease resistance of IL-12-deficient mice strongly argues in favor of the importance of Th1. However, it was later revealed that IL-23, which shares the $\mathrm{p} 40$ subunit with IL-12, but not IL-12, was required for the development of collagen-induced arthritis in an animal model of RA. ${ }^{71}$ Preserved IFN $\gamma$ and defective IL-17 production in IL-23p19-deficient mice suggested the importance of IL-17 in the development of the disease. This was supported by findings that mice lacking IL-17 and mice in which IL-17 was blocked were less susceptible to collageninduced arthritis. ${ }^{72-74}$ Thereafter, the importance of IL-17 was demonstrated in many, if not all, animal models of arthritis, including spontaneous arthritis in IL-1R $\alpha$-deficient mice and the SKG strain of mice. ${ }^{75,76}$ These results suggest that Th17 cells are the pathogenic CD4 T cells driving chronic inflammation in human RA.

There have been numerous studies examining IL-17 production in human RA. The first report by Chabaud et al detected bioactive IL-17 in the culture supernatants of synovial cells. ${ }^{77}$ Immunohistochemical analysis demonstrated IL-17-positive cells in RA synovium, which accounted for about $1 \%$ of $\mathrm{T}$ cells. Consistent with this, a recent study demonstrated that the majority of IL-17-producing cells in RA synovium were mast cells, while there were relatively few IL-17-producing T cells. ${ }^{78}$ An earlier study, in which the concentration of IL-17 was measured by using polyclonal antibodies against IL-17, showed very high levels of IL-17 in RA synovial fluid (SF) and serum. ${ }^{79}$ Although more recent studies also showed increased IL-17 production in RA SF compared with osteoarthritis SF, ${ }^{11,22,80,81}$ the levels were not as high as in the earlier report. Furthermore, a considerable portion of RA SF did not contain a detectable amount of IL-17. The concentration of IL-17 was even comparable between RA and osteoarthritis SF, but was increased in reactive arthritis and juvenile idiopathic arthritis. ${ }^{82,83}$ Raza et al reported that IL-17 production increased in the SF of early but not established RA. ${ }^{84}$ There are also several reports examining the expression of IL-17 transcripts in RA synovial membrane. Kirkham et al reported that increased levels of IL-17 mRNA expression predicted progression of joint damage, ${ }^{85}$ which fits well with the known biologic activity of IL-17. However, IL-17 mRNA was only detected in 15 of 54 RA patients, whereas IFN $\gamma$ mRNA was detected in 48 of 56 patients. Others also detected IL-17 mRNA in only about half of RA samples. ${ }^{86,87}$ No difference was found in the expression level of IL-17 mRNA between RA and osteoarthritis by qualitative real-time polymerase chain reaction. ${ }^{88}$ These findings are supported by studies examining the prevalence of Th17 cells by flow cytometry. The frequency of Th17 cells found in the peripheral blood of RA patients did not differ from controls, ${ }^{89,90}$ but was significantly increased in patients with psoriatic arthritis. Furthermore, Th1 cells predominated over Th17 cells in the joints, ${ }^{26,89}$ although the percentage of Th17 in CD4 T cells can be higher in joints than in blood, possibly due to the enrichment of CD45RO+ memory CD4 T cells. This is supported by earlier reports showing no increase of CCR6 expression in memory CD 4T cells in RA joints. ${ }^{91}$ In contrast with these findings, a recent report showed an increased proportion of Th17 cells in the peripheral blood of disease-modifying antirheumatic-drug naive RA patients. ${ }^{92}$ Together with the report by Raza et al this suggests the importance of Th17 at an early stage of the disease. ${ }^{84}$ A significant decrease of serum IL-17 after the onset of RA was also recently reported..$^{93}$

Although IL-23 is even more important than IL-17 for the development of animal models of arthritis, expression of IL-23 is not easily detected in RA. It was reported that the level of IL-23 protein in RA and osteoarthritis SF was comparably low, mainly due to defective IL-12/23p40 expression. ${ }^{94}$ Stamp et al detected a low level of expression of IL-23p19 in RA synovial membrane, which was higher in the samples with IL-17 expression (13 of 25) ${ }^{86}$ Therefore, unlike the case of CD or psoriatic lesions, IL-23 and IL-17 might not always be upregulated in RA synovium. In addition, it was reported that $\mathrm{CD}$ and psoriasis-associated variants of the $I L 23 R$ gene are not associated with RA. ${ }^{95,96}$ Of particular interest is the observation made by Hillyer et al that the addition of anti-IL-23 monoclonal antibody (mAb) to the synovial cell culture only partly reduced IL- $1 \beta, \mathrm{TNF} \alpha$, and IL-6 production. ${ }^{87}$ Furthermore, the effect of anti-IL-17 $\mathrm{mAb}$ was even weaker than anti-IL-23 mAb. These results 
were clearly different from what was shown two decades ago, ie, blocking TNF $\alpha$ in a similar culture system completely suppressed inflammatory cytokine production. ${ }^{97}$ Therefore, the importance of IL-17 in the pathogenesis of human RA could differ from that in animal models and remains an open question.

\section{Multiple sclerosis}

MS is an inflammatory demyelinating disease of the central nervous system. Experimental autoimmune encephalomyelitis (EAE) is an animal model of multiple sclerosis (MS) and is a prototype of T cell-mediated autoimmune disease. Thus, EAE is induced by either active immunization with myelin antigen or by adoptive transfer of myelin antigen-primed $\mathrm{T}$ cells, which enables us to address $\mathrm{T}$ cell functions easily. In fact, the importance of IL-23 in autoimmune inflammation was first demonstrated in this model, ${ }^{98}$ which led to the discovery of Th17 cells. However, the importance of the Th1 response in the pathogenesis of EAE was reevaluated more recently. While adoptive transfer of myelin-specific Th17 cells induced EAE characterized by neutrophil infiltration, Th1 cells transferred EAE with a macrophage-rich infiltrate. ${ }^{99}$ Expression of T-bet, irrespective of Th1 or Th17, was important for encephalitogenicity. ${ }^{100}$ Furthermore, it was shown that IL-17, IL-17F, and IL-22 were dispensable for the development of EAE, ${ }^{101,102}$ although there are also conflicting results. ${ }^{34}$ Thus, both Th1 and Th17 cells can be pathogenic in EAE.

Relatively few data are available on the involvement of IL-17 in the pathogenesis of human MS compared with mouse EAE or other human diseases, likely due to the difficulty in obtaining lesion samples. An increased frequency of mononuclear cells expressing IL-17 mRNA in the blood and spinal fluid of MS patients was reported. ${ }^{103}$ Transcriptional profiling of the genes expressed in MS lesions also demonstrated upregulation of IL-6 and IL-17. ${ }^{104}$ Ishizu et al reported increased levels of IL-17 and IL-8 in the spinal fluid of patients with the opticospinal form of MS, in which neutrophil infiltration is more prominent than in conventional MS. ${ }^{105}$ The frequency of Th17 cells but not Th1 cells in the peripheral blood was significantly increased in active MS patients. ${ }^{106}$ In another report, the frequency of Th17 cells in the spinal fluid, but not in peripheral blood, was increased during relapse. ${ }^{107}$ Histologic analysis also showed expression of IL-17 in active lesions. ${ }^{108}$ As for IL-23, peripheral blood monocyte-derived dendritic cells from MS patients had increased expression of IL-23p19. ${ }^{109}$ IL23p19 as well as IL-12/23p40 was also detected in active MS lesions. ${ }^{110}$ Although these results suggest the involvement of Th17 cells in the pathogenesis of human MS, there have also been reports showing the predominance of Th1 cells in myelin-specific T cells. ${ }^{11,112}$ The genetic association of MS with $I L 23 R$ polymorphism is controversial. ${ }^{113-116}$ In addition, it was observed that exacerbations of MS in patients treated with altered peptide ligand were associated with an increased Th1 response. ${ }^{117}$ MS was also exacerbated in patients treated with IFN $\gamma{ }^{118}$ Thus, similar to the case of mouse EAE, Th17 cells may not be the only pathogenic CD4 T cells in human MS.

\section{Current therapies for autoimmune diseases and effect on IL-I 7 or ThI 7 cells}

The treatment strategy and prognosis of autoimmune disease have greatly changed since the introduction of biologic agents, firstly anti-TNF $\alpha \mathrm{mAb}$ for RA. Thereafter, anti-IL-6 and anti-CD20 mAbs and soluble CTLA4-Ig have been demonstrated to be highly effective in RA and are now available worldwide. ${ }^{119}$ TNF $\alpha$ blockers have also been used in the treatment of CD and psoriasis. ${ }^{120,121}$ However, biological-based therapy is sometimes unsuccessful, even when a beneficial effect is expected. For example, blocking TNF $\alpha$ exerted deleterious effects on MS, ${ }^{122}$ although local TNF $\alpha$ production was shown to be increased in active MS, ${ }^{123}$ and TNF $\alpha$ has various biologic activities that can explain the pathogenesis of MS. ${ }^{124}$ In addition, blocking TNF $\alpha$ was effective in the animal model of MS and EAE, ${ }^{125}$ and $\mathrm{TNF} \alpha$-deficient mice were less susceptible to EAE. ${ }^{126}$ These findings remind us of an important lesson, ie, the pathogenesis of animal models and real human diseases are not necessarily identical.

There have been studies addressing the effects of current therapies on Th17 responses. Kageyama et al observed a significant decline in the level of IL-23 in the serum of RA patients after treatment with anti-TNF $\alpha \mathrm{mAb}$, which was significantly correlated with improved disease activity, although the level of IL-17 was unaffected. ${ }^{127}$ Yue et al reported, however, that the percentage of Th17 cells in peripheral blood tended to decrease after treatment with another antibody against $\mathrm{TNF} \alpha .{ }^{128}$ It was also shown in psoriasis patients that TNF $\alpha$ inhibition reduced local expression of Th17-related molecules, including IL-23, IL-22, IL-17, CCL20, and $\beta$-defensin $4 .^{129}$ These results suggest a downregulatory role of TNF $\alpha$ blockers on Th17 responses in vivo, either directly or indirectly as the result of reduced inflammation. A mAb against IL-6 receptor also effectively controls disease activity in RA. ${ }^{130}$ Because IL-6 was shown to be involved in the development of Th17 cells, an animal study anticipated that Th17 cells are one of the targets of therapy. ${ }^{131}$ On the other 
hand, in vitro analysis of human T cells showed that IL-6 plays a relatively minor role in the development of Th17 cells. ${ }^{3}$ In this regard, it is of interest to see the effect of blocking IL-1 $\beta$, because it plays a critical role in the differentiation of human Th17 cells. However, IL-1 $\beta$ blockade exerted only a modest effect in RA. ${ }^{132}$ In any case, the effects of IL-1 $\beta$ - or IL-6-targeted therapy on Th17 cells have not been reported so far. As for MS, IFN $\beta$ is widely used for its treatment, and some recent studies suggest the involvement of downregulation of Th17 responses. It was reported that Type I IFN receptor-deficient mice develop severe EAE with enhanced IL-17 production, ${ }^{133}$ although conflicting data were also demonstrated. ${ }^{134}$ In vitro experiments showed that IFN $\beta$ inhibits human Th17 differentiation directly or indirectly via dendritic cells. ${ }^{135}$ However, Drulovic et al reported that while IFN $\beta$ treatment reduced the level of IFN $\gamma$ and T-bet, it did not affect the level of IL-17 and RORc expression, ${ }^{136}$ again leaving a question about the importance of Th17 cells in MS.

\section{Clinical trials of reagents targeting Th I 7-related molecules in autoimmune diseases}

A clinical trial is the only way to prove the importance of a given target, because it sometimes has results which are unexpected from in vitro analysis or animal studies. It was revealed that administration of an anti-IL-12/23p40 mAb (ABT874) showed a therapeutic effect in patients with CD, with no increase of adverse events. ${ }^{137}$ Treatment with ABT874 decreased IFN $\gamma$, IL-12, IL-6, and TNF $\alpha$ secretion by mononuclear cells in the lamina propria. Impaired IL-17 production of lamina propria T cells was also reported later. ${ }^{138}$ A randomized trial of ustekinumab (CNTO 1275), another antihuman IL-12/23p40 mAb, in 104 patients with moderate to severe $\mathrm{CD}$ also showed a significant effect, even in patients who had previously been given antiTNF $\alpha$ mAb. ${ }^{139}$ In addition to these antibody-based drugs, a small oral dose of an IL-12/23 inhibitor, apilimod mesylate (STA 5326), was tested for CD. ${ }^{140}$ The action of apilimod includes selective inhibition of c-Rel translocation, which results in the suppressed transcription of IL-12/23p40 and IL-12p35. The results of a clinical trial showed that apilimod was well tolerated and clearly effective in moderate to severe CD. Blocking IL-12/23p40 is also highly effective for the treatment of psoriasis. ${ }^{141,142}$ For instance, a randomized, double-blind study revealed that ustekinumab was so effective that $66 \%$ of patients receiving $45 \mathrm{mg}$ of ustekinumab but only $3 \%$ of patients receiving placebo achieved a 75\% improvement of the psoriasis area and severity index. ${ }^{143}$ Furthermore, it was recently reported that ustekinumab was even more effective than the soluble TNF $\alpha$ receptor, etanercept, for the treatment of psoriasis. ${ }^{144}$ These results indicate that IL-12/23p40 plays a critical role in the pathogenesis of CD and psoriasis. However, as these reagents do not only affect Th17 responses, possible involvement of IFN $\gamma$ or Th1 responses in the pathogenesis is not excluded. It is also possible that IL-12 or IL-23 participate in the disease pathogenesis in a $\mathrm{T}$ cell-independent manner.

In contrast with the success in $\mathrm{CD}$ and psoriasis, a clinical trial of ustekinumab had disappointing results in MS. Up to $180 \mathrm{mg}$ of ustekinumab was administered weekly until three weeks, and every four weeks thereafter. The number of new lesions was evaluated at week 23 , but there was no reduction of lesions in the treatment group. Furthermore, there was no difference in the number of clinical or objective relapses. ${ }^{145}$ One may argue that the treatment should be applied at an early stage of the disease. However, administration of anti-IL-12/23p40 $\mathrm{mAb}$ as well as anti-IL-23p19 mAb was effective in EAE even after onset. ${ }^{146}$ Furthermore, the apparent clinical effect of blocking IL-12/23p40 in psoriasis and CD, irrespective of the duration of the disease, also argues against the idea. Therefore, it is more reasonable to assume that the pathology of MS, especially in the context of the cytokine network, is largely different from CD or psoriasis. This also reminds us of the different effect of TNF $\alpha$ blockade between MS and CD or psoriasis. As for RA, there has been no report of the therapeutic effect of targeting IL-12/23p40. However, the results of a Phase I trial of anti-IL-17 mAb (LY2439821) in the treatment of RA were recently published. ${ }^{147}$ Although a certain degree of improvement of disease activity has been shown, the effect does not seem to be as strong as for TNF $\alpha$ blockers. However, it might be too early to draw conclusions, because of the small subject number and relatively high improvement rates in the placebo group. There is another anti-IL-17 mAb (AIN457) being tested for RA, but detailed results of the trial have not been published so far. ${ }^{119}$ In view of the biologic functions of IL-17, blocking IL-17 may exert a clearer beneficial effect in suppression of joint destruction during long-term follow-up. In this regard, future combination therapy including a TNF $\alpha$ blocker is of particular interest. To date, there has been no report of the effects of blocking IL-17 or other Th17-related cytokines in other human autoimmune diseases.

\section{Conclusions}

The discovery of IL-17 has led to novel insights into the pathogenesis of several autoimmune diseases, and the importance of IL-17 has been demonstrated in various animal models. However, it has become clear that there is a large 
variation in the therapeutic effect of targeting IL-17-related molecules in human autoimmune diseases. Further clinical trials might clarify the whole picture. At the same time, these findings also provoke the need for a better understanding of the differences between human and mouse immune systems, and for the development of better disease models, in order to avoid unnecessary clinical trials with their inevitable risk of adverse events.

\section{Disclosure}

The author reports no conflict of interest in this work.

\section{References}

1. Rouvier E, Luciani MF, Mattei MG, Denizot F, Golstein P. CTLA-8, cloned from an activated $\mathrm{T}$ cell, bearing AU-rich messenger RNA instability sequences, and homologous to a herpesvirus saimiri gene. J Immunol. 1993;150(12):5445-5456.

2. Yao Z, Painter SL, Fanslow WC, et al. Human IL-17: A novel cytokine derived from T cells. J Immunol. 1995;155(12):5483-5486.

3. de Jong E, Suddason T, Lord GM. Translational mini-review series on Th17 cells: Development of mouse and human T helper 17 cells. Clin Exp Immunol. 2009;159(2):148-158.

4. Fossiez F, Djossou O, Chomarat P, et al. T cell interleukin-17 induces stromal cells to produce proinflammatory and hematopoietic cytokines. J Exp Med. 1996;183(6):2593-2603.

5. Matsuzaki G, Umemura M. Interleukin-17 as an effector molecule of innate and acquired immunity against infections. Microbiol Immunol. 2007;51(12):1139-1147.

6. Liang SC, TanXY, Luxenberg DP, et al. Interleukin (IL)-22 and IL-17 are coexpressed by Th17 cells and cooperatively enhance expression of antimicrobial peptides. J Exp Med. 2006;203(10):2271-2279.

7. Acosta-Rodriguez EV, Rivino L, Geginat J, et al. Surface phenotype and antigenic specificity of human interleukin 17-producing $\mathrm{T}$ helper memory cells. Nat Immunol. 2007;8(6):639-646.

8. Paulson ML, Freeman AF, Holland SM. Hyper IgE syndrome: An update on clinical aspects and the role of signal transducer and activator of transcription 3. Curr Opin Allergy Clin Immunol. 2008;8(6):527-533.

9. Jovanovic DV, Di Battista JA, Martel-Pelletier J, et al. IL-17 stimulates the production and expression of proinflammatory cytokines, IL-beta and TNF-alpha, by human macrophages. J Immunol. 1998;160(7): 3513-3521.

10. Jovanovic DV, Martel-Pelletier J, Di Battista JA, et al. Stimulation of 92-kd gelatinase (matrix metalloproteinase 9) production by interleukin-17 in human monocyte/macrophages: A possible role in rheumatoid arthritis. Arthritis Rheum. 2000;43(5):1134-1144.

11. Kotake S, Udagawa N, Takahashi N, et al. IL-17 in synovial fluids from patients with rheumatoid arthritis is a potent stimulator of osteoclastogenesis. J Clin Invest. 1999;103(9):1345-1352.

12. Yagi Y, Andoh A, Inatomi O, Tsujikawa T, Fujiyama Y. Inflammatory responses induced by interleukin-17 family members in human colonic subepithelial myofibroblasts. J Gastroenterol. 2007;42(9): 746-753.

13. Albanesi C, Scarponi C, Cavani A, et al. Interleukin-17 is produced by both Th1 and Th2 lymphocytes, and modulates interferon-gammaand interleukin-4-induced activation of human keratinocytes. $J$ Invest Dermatol. 2000;115(1):81-87.

14. Kebir H, Kreymborg K, Ifergan I, et al. Human TH17 lymphocytes promote blood-brain barrier disruption and central nervous system inflammation. Nat Med. 2007;13(10):1173-1175.

15. Aarvak T, Chabaud M, Miossec P, Natvig JB. IL-17 is produced by some proinflammatory Th1/Th0 cells but not by Th2 cells. J Immunol. 1999;162(3):1246-1251.
16. Annunziato F, Cosmi L, Santarlasci V, et al. Phenotypic and functional features of human Th17 cells. J Exp Med. 2007;204(8):1849-1861.

17. Yang XO, Pappu BP, Nurieva R, et al. T helper 17 lineage differentiation is programmed by orphan nuclear receptors ROR alpha and ROR gamma. Immunity. 2008;28(1):29-39.

18. Acosta-Rodriguez EV, Napolitani G, Lanzavecchia A, Sallusto F. Interleukins 1 beta and 6 but not transforming growth factor-beta are essential for the differentiation of interleukin 17-producing human $\mathrm{T}$ helper cells. Nat Immunol. 2007;8(9):942-949.

19. Santarlasci V, Maggi L, Capone M, et al. TGF-beta indirectly favors the development of human Th17 cells by inhibiting Th1 cells. Eur J Immunol. 2009;39(1):207-215.

20. Cosmi L, De Palma R, Santarlasci V, et al. Human interleukin 17-producing cells originate from a CD161+CD4+ T cell precursor. J Exp Med. 2008;205(8):1903-1916.

21. Michel ML, Keller AC, Paget C, et al. Identification of an IL-17producing NK1.1(neg) iNKT cell population involved in airway neutrophilia. J Exp Med. 2007;204(5):995-1001.

22. Hirota K, Yoshitomi H, Hashimoto M, et al. Preferential recruitment of CCR6-expressing Th17 cells to inflamed joints via CCL20 in rheumatoid arthritis and its animal model. J Exp Med. 2007;204(1):2803-2812.

23. Nurieva RI, Chung Y, Hwang D, et al. Generation of T follicular helper cells is mediated by interleukin-21 but independent of T helper 1, 2, or 17 cell lineages. Immunity. 2008;29(1):138-149.

24. Eyerich S, Eyerich K, Pennino D, et al. Th22 cells represent a distinct human $\mathrm{T}$ cell subset involved in epidermal immunity and remodeling. J Clin Invest. 2009;119(12):3573-3585.

25. Takatori H, Kanno Y, Watford WT, et al. Lymphoid tissue inducer-like cells are an innate source of IL-17 and IL-22. J Exp Med. 2009;206(1): 35-41.

26. Ito Y, Usui T, Kobayashi S, et al. Gamma/delta $\mathrm{T}$ cells are the predominant source of interleukin-17 in affected joints in collagen-induced arthritis, but not in rheumatoid arthritis. Arthritis Rheum. 2009;60(8): 2294-2303.

27. Lees JR, Iwakura Y, Russell JH. Host T cells are the main producers of IL-17 within the central nervous system during initiation of experimental autoimmune encephalomyelitis induced by adoptive transfer of Th1 cell lines. J Immunol. 2008;180(12):8066-8072.

28. Bouma G, Strober W. The immunological and genetic basis of inflammatory bowel disease. Nat Rev Immunol. 2003;3(7):521-533.

29. Hue S, Ahern P, Buonocore S, et al. Interleukin-23 drives innate and T cell-mediated intestinal inflammation. J Exp Med. 2006;203(11): 2473-2483.

30. Yen D, Cheung J, Scheerens H, et al. IL-23 is essential for T cellmediated colitis and promotes inflammation via IL-17 and IL-6. J Clin Invest. 2006;116(5):1310-1316.

31. Noguchi E, Homma Y, Kang X, Netea MG, Ma XA. Crohn's diseaseassociated NOD2 mutation suppresses transcription of human IL10 by inhibiting activity of the nuclear ribonucleoprotein hnRNP-A1. Nat Immunol. 2009;10(5):471-479.

32. Elson CO, Cong Y, Weaver CT, et al. Monoclonal anti-interleukin 23 reverses active colitis in a T cell-mediated model in mice. Gastroenterology. 2007;132(7):2359-2370.

33. O’Connor W Jr, Kamanaka M, Booth CJ, et al. A protective function for interleukin 17A in T cell-mediated intestinal inflammation. Nat Immunol. 2009;10(6):603-609.

34. Yang XO, Chang SH, Park H, et al. Regulation of inflammatory responses by IL-17F. J Exp Med. 2008;205(5):1063-1075.

35. Powrie F, Leach MW, Mauze S, Menon S, Caddle LB, Coffman RL. Inhibition of Th1 responses prevents inflammatory bowel disease in scid mice reconstituted with CD45RBhi CD4+ T cells. Immunity. 1994;1(7):553-562.

36. Nielsen OH, Kirman I, Rudiger N, Hendel J, Vainer B. Upregulation of interleukin-12 and -17 in active inflammatory bowel disease. Scand J Gastroenterol. 2003;38(2):180-185.

37. Fujino S, Andoh A, Bamba S, et al. Increased expression of interleukin 17 in inflammatory bowel disease. Gut. 2003;52(1):65-70. 
38. Schmidt C, Giese T, Ludwig B, et al. Expression of interleukin-12related cytokine transcripts in inflammatory bowel disease: Elevated interleukin-23p19 and interleukin-27p28 in Crohn's disease but not in ulcerative colitis. Inflamm Bowel Dis. 2005;11(1):16-23.

39. Holtta V, Klemetti P, Sipponen T, et al. IL-23/IL-17 immunity as a hallmark of Crohn's disease. Inflamm Bowel Dis. 2008;14(9):1175-1184.

40. Andoh A, Zhang Z, Inatomi O, et al. Interleukin-22, a member of the IL-10 subfamily, induces inflammatory responses in colonic subepithelial myofibroblasts. Gastroenterology. 2005;129(3):969-984.

41. Wolk K, Witte E, Hoffmann U, et al. IL-22 induces lipopolysaccharidebinding protein in hepatocytes: A potential systemic role of IL-22 in Crohn's disease. J Immunol. 2007;178(9):5973-5981.

42. Seiderer J, Elben I, Diegelmann J, et al. Role of the novel Th17 cytokine IL-17F in inflammatory bowel disease (IBD): Upregulated colonic IL-17F expression in active Crohn's disease and analysis of the IL17F p.His161Arg polymorphism in IBD. Inflamm Bowel Dis. 2008;14(4):437-445.

43. Duerr RH, Taylor KD, Brant SR, et al. A genome-wide association study identifies IL23R as an inflammatory bowel disease gene. Science. 2006;314(5804):1461-1463.

44. Sato K, Shiota M, Fukuda S, et al. Strong evidence of a combination polymorphism of the tyrosine kinase 2 gene and the signal transducer and activator of transcription 3 gene as a DNA-based biomarker for susceptibility to Crohn's disease in the Japanese population. $J$ Clin Immunol. 2009;29(6):815-825.

45. Kleinschek MA, Boniface K, Sadekova S, et al. Circulating and gut-resident human Th17 cells express CD161 and promote intestinal inflammation. J Exp Med. 2009;206(3):525-534.

46. Fuss IJ, Heller F, Boirivant M, et al. Nonclassical CD1d-restricted NK $\mathrm{T}$ cells that produce IL-13 characterize an atypical Th2 response in ulcerative colitis. J Clin Invest. 2004;113(10):1490-1497.

47. Kobayashi T, Okamoto S, Hisamatsu T, et al. IL23 differentially regulates the Th1/Th17 balance in ulcerative colitis and Crohn's disease. Gut. 2008;57(12):1682-1689.

48. Rovedatti L, Kudo T, Biancheri P, et al. Differential regulation of interleukin 17 and interferon gamma production in inflammatory bowel disease. Gut. 2009;58(12):1629-1636.

49. Kamada N, Hisamatsu T, Okamoto S, et al. Unique CD14 intestinal macrophages contribute to the pathogenesis of Crohn disease via IL-23/ IFN-gamma axis. J Clin Invest. 2008;118(6):2269-2280.

50. Teunissen MB, Koomen CW, de Waal Malefyt R, Wierenga EA, Bos JD. Interleukin-17 and interferon-gamma synergize in the enhancement of proinflammatory cytokine production by human keratinocytes. J Invest Dermatol. 1998;111(4):645-649.

51. Lowes MA, Kikuchi T, Fuentes-Duculan J, et al. Psoriasis vulgaris lesions contain discrete populations of Th1 and Th17 T cells. J Invest Dermatol. 2008;128(5):1207-1211.

52. Chan JR, Blumenschein W, Murphy E, et al. IL-23 stimulates epidermal hyperplasia via TNF and IL-20R2-dependent mechanisms with implications for psoriasis pathogenesis. J Exp Med. 2006;203(12): $2577-2587$.

53. Wilson NJ, Boniface K, Chan JR, et al. Development, cytokine profile and function of human interleukin 17-producing helper T cells. Nat Immunol. 2007;8(9):950-957.

54. Arican O, Aral M, Sasmaz S, Ciragil P. Serum levels of TNF-alpha, IFN-gamma, IL-6, IL-8, IL-12, IL-17, and IL-18 in patients with active psoriasis and correlation with disease severity. Mediators Inflamm. 2005;2005(5):273-279.

55. Kryczek I, Bruce AT, Gudjonsson JE, et al. Induction of IL-17+ T cell trafficking and development by IFN-gamma: Mechanism and pathological relevance in psoriasis. J Immunol. 2008;181(7):4733-4741.

56. Homey B, Dieu-Nosjean MC, Wiesenborn A, et al. Up-regulation of macrophage inflammatory protein-3 alpha/CCL20 and CC chemokine receptor 6 in psoriasis. J Immunol. 2000;164(12):6621-6632.

57. Lee E, Trepicchio WL, Oestreicher JL, et al. Increased expression of interleukin 23 p19 and p40 in lesional skin of patients with psoriasis vulgaris. $J$ Exp Med. 2004;199(1):125-130.
58. Piskin G, Sylva-Steenland RM, Bos JD, Teunissen MB. In vitro and in situ expression of IL-23 by keratinocytes in healthy skin and psoriasis lesions: Enhanced expression in psoriatic skin. J Immunol. 2006; 176(3):1908-1915.

59. Capon F, Di Meglio P, Szaub J, et al. Sequence variants in the genes for the interleukin-23 receptor (IL23R) and its ligand (IL12B) confer protection against psoriasis. Hum Genet. 2007;122(2):201-206.

60. Cargill M, Schrodi SJ, Chang M, et al. A large-scale genetic association study confirms IL12B and leads to the identification of IL23R as psoriasis-risk genes. Am J Hum Genet. 2007;80(2):273-290.

61. Zheng Y, Danilenko DM, Valdez P, et al. Interleukin-22, a $\mathrm{T}(\mathrm{H}) 17$ cytokine, mediates IL-23-induced dermal inflammation and acanthosis. Nature. 2007;445(7128):648-651.

62. Ma HL, Liang S, Li J, et al. IL-22 is required for Th17 cell-mediated pathology in a mouse model of psoriasis-like skin inflammation. J Clin Invest. 2008;118(2):597-607.

63. Wolk K, Kunz S, Witte E, Friedrich M, Asadullah K, Sabat R. IL-22 increases the innate immunity of tissues. Immunity. 2004;21(2): 241-254.

64. Boniface K, Bernard FX, Garcia M, Gurney AL, Lecron JC, Morel F. IL-22 inhibits epidermal differentiation and induces proinflammatory gene expression and migration of human keratinocytes. $J$ Immunol. 2005; 174(6):3695-3702.

65. Wolk K, Witte E, Wallace E, et al. IL-22 regulates the expression of genes responsible for antimicrobial defense, cellular differentiation, and mobility in keratinocytes: A potential role in psoriasis. Eur J Immunol. 2006;36(5):1309-1323.

66. Duhen T, Geiger R, Jarrossay D, Lanzavecchia A, Sallusto F. Production of interleukin 22 but not interleukin 17 by a subset of human skin-homing memory T cells. Nat Immunol. 2009;10(8):857-863.

67. Trifari S, Kaplan CD, Tran EH, Crellin NK, Spits H. Identification of a human helper $\mathrm{T}$ cell population that has abundant production of interleukin 22 and is distinct from $\mathrm{T}(\mathrm{H})-17, \mathrm{~T}(\mathrm{H}) 1$ and $\mathrm{T}(\mathrm{H}) 2$ cells. Nat Immunol. 2009;10(8):864-871.

68. Nograles KE, Zaba LC, Guttman-Yassky E, et al. Th17 cytokines interleukin (IL)-17 and IL-22 modulate distinct inflammatory and keratinocyte-response pathways. Br J Dermatol. 2008;159(5): 1092-1102.

69. Steiner G, Tohidast-Akrad M, Witzmann G, et al. Cytokine production by synovial $\mathrm{T}$ cells in rheumatoid arthritis. Rheumatology (Oxford). 1999;38(3):202-213.

70. Tesmer LA, Lundy SK, Sarkar S, Fox DA. Th17 cells in human disease. Immunol Rev. 2008;223:87-113.

71. Murphy CA, Langrish CL, Chen Y, et al. Divergent pro- and antiinflammatory roles for IL-23 and IL-12 in joint autoimmune inflammation. J Exp Med. 2003;198(12):1951-1957.

72. Nakae S, Nambu A, Sudo K, Iwakura Y. Suppression of immune induction of collagen-induced arthritis in IL-17-deficient mice. J Immunol. 2003; 171(11):6173-6177.

73. Lubberts E, Koenders MI, Oppers-Walgreen B, et al. Treatment with a neutralizing anti-murine interleukin-17 antibody after the onset of collagen-induced arthritis reduces joint inflammation, cartilage destruction, and bone erosion. Arthritis Rheum. 2004;50(2):650-659.

74. Bush KA, Farmer KM, Walker JS, Kirkham BW. Reduction of joint inflammation and bone erosion in rat adjuvant arthritis by treatment with interleukin-17 receptor IgG1 Fc fusion protein. Arthritis Rheum. 2002;46(3):802-805.

75. Nakae S, Saijo S, Horai R, Sudo K, Mori S, Iwakura Y. IL-17 production from activated $\mathrm{T}$ cells is required for the spontaneous development of destructive arthritis in mice deficient in IL-1 receptor antagonist. Proc Natl Acad Sci U SA. 2003;100(10):5986-5990.

76. Hirota K, Hashimoto M, Yoshitomi H, et al. T cell self-reactivity forms a cytokine milieu for spontaneous development of IL-17+ Th cells that cause autoimmune arthritis. J Exp Med. 2007;204(1):41-47.

77. Chabaud M, Durand JM, Buchs N, et al. Human interleukin-17: A T cell-derived proinflammatory cytokine produced by the rheumatoid synovium. Arthritis Rheum. 1999;42(5):963-970. 
78. Hueber AJ, Asquith DL, Miller AM, et al. Cutting edge: Mast cells express IL-17A in rheumatoid arthritis synovium. J Immunol. 2010; 184(7):3336-3340.

79. Ziolkowska M, Koc A, Luszczykiewicz G, et al. High levels of IL-17 in rheumatoid arthritis patients: IL-15 triggers in vitro IL-17 production via cyclosporin A-sensitive mechanism. J Immunol. 2000;164(5): 2832-2838.

80. Hussein MR, Fathi NA, El-Din AM, et al. Alterations of the CD4(+), CD8(+) T cell subsets, interleukins-1beta, IL-10, IL-17, tumor necrosis factor-alpha and soluble intercellular adhesion molecule-1 in rheumatoid arthritis and osteoarthritis: Preliminary observations. Pathol Oncol Res. 2008;14(3):321-328.

81. Moran EM, Mullan R, McCormick J, et al. Human rheumatoid arthritis tissue production of IL-17A drives matrix and cartilage degradation: Synergy with tumour necrosis factor-alpha, Oncostatin $\mathrm{M}$ and response to biologic therapies. Arthritis Res Ther. 2009;11(4):R113.

82. Singh R, Aggarwal A, Misra R. Th1/Th17 cytokine profiles in patients with reactive arthritis/undifferentiated spondyloarthropathy. J Rheumatol. 2007;34(11):2285-2290.

83. Agarwal S, Misra R, Aggarwal A. Interleukin 17 levels are increased in juvenile idiopathic arthritis synovial fluid and induce synovial fibroblasts to produce proinflammatory cytokines and matrix metalloproteinases. J Rheumatol. 2008;35(3):515-519.

84. Raza K, Falciani F, Curnow SJ, et al. Early rheumatoid arthritis is characterized by a distinct and transient synovial fluid cytokine profile of T cell and stromal cell origin. Arthritis Res Ther. 2005;7(4):R784-R785.

85. Kirkham BW, Lassere MN, Edmonds JP, et al. Synovial membrane cytokine expression is predictive of joint damage progression in rheumatoid arthritis: A two-year prospective study (the DAMAGE study cohort). Arthritis Rheum. 2006;54(4):1122-1131.

86. Stamp LK, Easson A, Pettersson L, Highton J, Hessian PA. Monocyte derived interleukin (IL)-23 is an important determinant of synovial IL-17A expression in rheumatoid arthritis. J Rheumatol. 2009;36(11):2403-2408.

87. Hillyer P, Larche M, J Bowma EP, et al. Investigating the role of the interleukin-23/-17A axis in rheumatoid arthritis. Rheumatology (Oxford). 2009;48(12):1581-1589.

88. Kohno M, Tsutsumi A, Matsui H, et al. Interleukin-17 gene expression in patients with rheumatoid arthritis. Mod Rheumatol. 2008;18(1):15-22.

89. Yamada H, Nakashima Y, Okazaki K, et al. Th1 but not Th17 cells predominate in the joints of patients with rheumatoid arthritis. Ann Rheum Dis. 2008;67(9):1299-1304.

90. Jandus C, Bioley G, Rivals JP, Dudler J, Speiser D, Romero P. Increased numbers of circulating polyfunctional Th17 memory cells in patients with seronegative spondylarthritides. Arthritis Rheum. 2008; 58(8):2307-2317.

91. Burman A, Haworth O, Hardie DL, et al. A chemokine-dependent stromal induction mechanism for aberrant lymphocyte accumulation and compromised lymphatic return in rheumatoid arthritis. J Immunol. 2005;174(3):1693-1700.

92. Colin EM, Asmawidjaja PS, van Hamburg JP, et al. 1,25-dihydroxyvitamin $\mathrm{D}(3)$ modulates Th17 polarization and interleukin-22 expression by memory T cells from patients with early rheumatoid arthritis. Arthritis Rheum. 2010;62(1):132-142.

93. Kokkonen H, Soderstrom I, Rocklov J, Hallmans G, Lejon K, Rantapaa Dahlqvist S. Up-regulation of cytokines and chemokines predates the onset of rheumatoid arthritis. Arthritis Rheum. 2010;62(2):383-391.

94. Brentano F, Ospelt C, Stanczyk J, Gay RE, Gay S, Kyburz D. Abundant expression of the interleukin (IL)23 subunit p19, but low levels of bioactive IL23 in the rheumatoid synovium: Differential expression and Toll-like receptor-(TLR) dependent regulation of the IL23 subunits, p19 and p40, in rheumatoid arthritis. Ann Rheum Dis. 2009;68(1): 143-150.

95. Chang M, Saiki RK, Cantanese JJ, et al. The inflammatory diseaseassociated variants in IL12B and IL23R are not associated with rheumatoid arthritis. Arthritis Rheum. 2008;58(6):1877-1881.
96. Park JH, Kim YJ, Park BL, Bae JS, Shin HD, Bae SC. Lack of association between interleukin 23 receptor gene polymorphisms and rheumatoid arthritis susceptibility. Rheumatol Int. 2009;29(7):781-786.

97. Brennan FM, Chantry D, Jackson A, Maini R, Feldmann M. Inhibitory effect of TNF alpha antibodies on synovial cell interleukin-1 production in rheumatoid arthritis. Lancet. 1989;2(8657):244-247.

98. Cua DJ, Sherlock J, Chen Y, et al. Interleukin-23 rather than interleukin-12 is the critical cytokine for autoimmune inflammation of the brain. Nature. 2003;421(6924):744-748.

99. Kroenke MA, Carlson TJ, Andjelkovic AV, Segal BM. IL-12- and IL-23-modulated T cells induce distinct types of EAE based on histology, CNS chemokine profile, and response to cytokine inhibition. J Exp Med. 2008;205(7):1535-1541.

100. Yang Y, Weiner J, Liu Y, et al. T-bet is essential for encephalitogenicity of both Th1 and Th17 cells. J Exp Med. 2009;206(7):1549-1564.

101. Haak S, Croxford AL, Kreymborg K, et al. IL-17A and IL-17F do not contribute vitally to autoimmune neuro-inflammation in mice. J Clin Invest. 2009;119(1):61-69.

102. Kreymborg K, Etzensperger R, Dumoutier L, et al. IL-22 is expressed by Th17 cells in an IL-23-dependent fashion, but not required for the development of autoimmune encephalomyelitis. J Immunol. 2007; 179(12):8098-8104.

103. Matusevicius D, Kivisakk P, He B, et al. Interleukin-17 mRNA expression in blood and CSF mononuclear cells is augmented in multiple sclerosis. Mult Scler. 1999;5(2):101-104.

104. Lock C, Hermans G, Pedotti R, et al. Gene-microarray analysis of multiple sclerosis lesions yields new targets validated in autoimmune encephalomyelitis. Nat Med. 2002;8(5):500-508.

105. Ishizu T, Osoegawa M, Mei FJ, et al. Intrathecal activation of the IL-17/IL-8 axis in opticospinal multiple sclerosis. Brain. 2005;128(5): 988-1002.

106. Durelli L, Conti L, Clerico M, et al. T-helper 17 cells expand in multiple sclerosis and are inhibited by interferon-beta. Ann Neurol. 2009;65(5):499-509.

107. Brucklacher-Waldert V, Stuerner K, Kolster M, Wolthausen J, Tolosa E. Phenotypical and functional characterization of $\mathrm{T}$ helper 17 cells in multiple sclerosis. Brain. 2009;132(12):3329-3341.

108. Tzartos JS, Friese MA, Craner MJ, et al. Interleukin-17 production in central nervous system-infiltrating $\mathrm{T}$ cells and glial cells is associated with active disease in multiple sclerosis. Am J Pathol. 2008;172(1):146-155.

109. Vaknin-Dembinsky A, Balashov K, Weiner HL. IL-23 is increased in dendritic cells in multiple sclerosis and down-regulation of IL-23 by antisense oligos increases dendritic cell IL-10 production. J Immunol. 2006;176(12):7768-7774.

110. Li Y, Chu N, Hu A, Gran B, Rostami A, Zhang GX. Increased IL-23p19 expression in multiple sclerosis lesions and its induction in microglia. Brain. 2007;130(2):490-501.

111. Pelfrey CM, Rudick RA, Cotleur AC, Lee JC, Tary-Lehmann M, Lehmann PV. Quantification of self-recognition in multiple sclerosis by single-cell analysis of cytokine production. J Immunol. 2000;165(3): 1641-1651.

112. Voskuhl RR, Martin R, Bergman C, Dalal M, Ruddle NH, McFarland HF T helper 1 (Th1) functional phenotype of human myelin basic proteinspecific T lymphocytes. Autoimmunity. 1993;15(2): 137-143.

113. Begovich AB, Chang M, Caillier SJ, et al. The autoimmune diseaseassociated IL12B and IL23R polymorphisms in multiple sclerosis. Hum Immunol. 2007;68(11):934-937.

114. Nunez C, Dema B, Cenit MC, et al. IL23R: A susceptibility locus for celiac disease and multiple sclerosis? Genes Immun. 2008;9(4): 289-293.

115. Roos IM, Kockum I, Hillert J. The interleukin 23 receptor gene in multiple sclerosis: A case-control study. J Neuroimmunol. 2008;194(1-2):173-180.

116. Illes Z, Safrany E, Peterfalvi A, et al. 3'UTR C2370A allele of the IL-23 receptor gene is associated with relapsing-remitting multiple sclerosis. Neurosci Lett. 2008;431(1):36-38. 
117. Bielekova B, Goodwin B, Richert N, et al. Encephalitogenic potential of the myelin basic protein peptide (amino acids 83-99) in multiple sclerosis: Results of a phase II clinical trial with an altered peptide ligand. Nat Med. 2000;6(10):1167-1175.

118. Panitch HS, Hirsch RL, Haley AS, Johnson KP. Exacerbations of multiple sclerosis in patients treated with gamma interferon. Lancet. 1987;1(8538):893-895.

119. Senolt L, Vencovsky J, Pavelka K, Ospelt C, Gay S. Prospective new biological therapies for rheumatoid arthritis. Autoimmun Rev. 2009;9(2):102-107.

120. Targan SR, Hanauer SB, van Deventer SJ, et al. A short-term study of chimeric monoclonal antibody cA2 to tumor necrosis factor alpha for Crohn's disease. Crohn's Disease cA2 Study Group. N Engl J Med. 1997;337(15):1029-1035.

121. Reich K, Nestle FO, Papp K, et al. Infliximab induction and maintenance therapy for moderate-to-severe psoriasis: A phase III, multicentre, double-blind trial. Lancet. 2005;366(9494):1367-1374.

122. van Oosten BW, Barkhof F, Truyen L, et al. Increased MRI activity and immune activation in two multiple sclerosis patients treated with the monoclonal anti-tumor necrosis factor antibody cA2. Neurology. 1996;47(6):1531-1534.

123. Sharief MK, Hentges R. Association between tumor necrosis factor-alpha and disease progression in patients with multiple sclerosis. N Engl J Med. 1991;325(7):467-472.

124. Selmaj KW, Raine CS. Tumor necrosis factor mediates myelin and oligodendrocyte damage in vitro. Ann Neurol. 1988;23(4):339-346.

125. Ruddle NH, Bergman CM, McGrath KM, et al. An antibody to lymphotoxin and tumor necrosis factor prevents transfer of experimental allergic encephalomyelitis. J Exp Med. 1990;172(4):1193-1200.

126. Korner H, Riminton DS, Strickland DH, Lemckert FA, Pollard JD, Sedgwick JD. Critical points of tumor necrosis factor action in central nervous system autoimmune inflammation defined by gene targeting. J Exp Med. 1997;186(9):1585-1590.

127. Kageyama Y, Kobayashi H, Kato N. Infliximab treatment reduces the serum levels of interleukin-23 in patients with rheumatoid arthritis. Mod Rheumatol. 2009;19(6):657-662.

128. Yue C, You X, Zhao L, et al. The effects of adalimumab and methotrexate treatment on peripheral Th17 cells and IL-17/IL-6 secretion in rheumatoid arthritis patients. Rheumatol Int. 2009 Oct 22, [Epub ahead of print].

129. Zaba LC, Cardinale I, Gilleaudeau P, et al. Amelioration of epidermal hyperplasia by TNF inhibition is associated with reduced Th17 responses. J Exp Med. 2007;204(13):3183-3194.

130. Maini RN, Taylor PC, Szechinski J, et al. Double-blind randomized controlled clinical trial of the interleukin- 6 receptor antagonist, tocilizumab, in European patients with rheumatoid arthritis who had an incomplete response to methotrexate. Arthritis Rheum. 2006;54(9): 2817-2829.

131. Fujimoto M, Serada S, Mihara M, et al. Interleukin-6 blockade suppresses autoimmune arthritis in mice by the inhibition of inflammatory Th17 responses. Arthritis Rheum. 2008;58(12):3710-3719.

132. Mertens M, Singh JA. Anakinra for rheumatoid arthritis: A systematic review. J Rheumatol. 2009;36(6):1118-1125.
133. Guo B, Chang EY, Cheng G. The type I IFN induction pathway constrains Th17-mediated autoimmune inflammation in mice. J Clin Invest. 2008;118(5):1680-1690.

134. Prinz M, Schmidt H, Mildner A, et al. Distinct and nonredundant in vivo functions of IFNAR on myeloid cells limit autoimmunity in the central nervous system. Immunity. 2008;28(5):675-686.

135. Ramgolam VS, Sha Y, Jin J, Zhang X, Markovic-Plese S. IFN-beta inhibits human Th17 cell differentiation. J Immunol. 2009;183(8): 5418-5427.

136. Drulovic J, Savic E, Pekmezovic T, et al. Expression of Th1 and Th17 cytokines and transcription factors in multiple sclerosis patients: Does baseline T-bet mRNA predict the response to interferon-beta treatment? J Neuroimmunol. 2009;215(1-2):90-95.

137. Mannon PJ, Fuss IJ, Mayer L, et al. Anti-interleukin-12 antibody for active Crohn's disease. N Engl J Med. 2004;351(20):2069-2079.

138. Fuss IJ, Becker C, Yang Z, et al. Both IL-12p70 and IL-23 are synthesized during active Crohn's disease and are down-regulated by treatment with anti-IL-12 p40 monoclonal antibody. Inflamm Bowel Dis. 2006;12(1):9-15.

139. Sandborn WJ, Feagan BG, Fedorak RN, et al. A randomized trial of Ustekinumab, a human interleukin-12/23 monoclonal antibody, in patients with moderate-to-severe Crohn's disease. Gastroenterology. 2008;135(4):1130-1141.

140. Burakoff R, Barish CF, Riff, D, et al. A phase 1/2A trial of STA 5326, an oral interleukin-12/23 inhibitor, in patients with active moderate to severe Crohn's disease. Inflamm Bowel Dis. 2006;12(7):558-565.

141. Krueger GG, Langley RG, Leonardi C, et al. A human interleukin12/23 monoclonal antibody for the treatment of psoriasis. $N$ Engl J Med. 2007;356(6):580-592.

142. Kimball AB, Gordon KB, Langley RG, Menter A, Chartash EK, Valdes J. Safety and efficacy of ABT-874, a fully human interleukin $12 / 23$ monoclonal antibody, in the treatment of moderate to severe chronic plaque psoriasis: Results of a randomized, placebo-controlled, phase 2 trial. Arch Dermatol. 2008;144(2):200-207.

143. Leonardi CL, Kimball AB, Papp KA, et al. Efficacy and safety of ustekinumab, a human interleukin-12/23 monoclonal antibody, in patients with psoriasis: 76-week results from a randomised, double-blind, placebo-controlled trial (PHOENIX 1). Lancet. 2008;371(9625):1665-1674.

144. Griffiths CE, Strober BE, van de Kerkhof P, et al. Comparison of ustekinumab and etanercept for moderate-to-severe psoriasis. $\mathrm{N} \mathrm{Engl}$ J Med. 2010;362(2):118-128.

145. Segal BM, Constantinescu CS, Raychaudhuri A, Kim L, FidelusGort R, Kasper LH. Repeated subcutaneous injections of IL12/23 p40 neutralising antibody, ustekinumab, in patients with relapsing-remitting multiple sclerosis: A phase II, double-blind, placebo-controlled, randomised, dose-ranging study. Lancet Neurol. 2008;7(9):796-804.

146. Chen Y, Langrish CL, McKenzie B, et al. Anti-IL-23 therapy inhibits multiple inflammatory pathways and ameliorates autoimmune encephalomyelitis. J Clin Invest. 2006;116(5):1317-1326.

147. Genovese M, Van den Bosch F, Roberson S, et al. LY2439821, a humanized anti-IL-17 monoclonal antibody, in the treatment of patients with rheumatoid arthritis. Arthritis Rheum. 2010;62(4):929-939.

Journal of Inflammation Research

\section{Publish your work in this journal}

The Journal of Inflammation Research is an international, peer-reviewed open-access journal that welcomes laboratory and clinical findings on the molecular basis, cell biology and pharmacology of inflammation including original research, reviews, symposium reports, hypothesis formation and commentaries on: acute/chronic inflammation; mediators of inflamma-

tion; cellular processes; molecular mechanisms; pharmacology and novel anti-inflammatory drugs; clinical conditions involving inflammation. The manuscript management system is completely online and includes a very quick and fair peer-review system. Visit http://www.dovepress.com/ testimonials.php to read real quotes from published authors. 